\title{
Epidemiology of hepatitis B, C and D in Malawi: systematic review
}

\author{
Alexander J Stockdale ${ }^{1,2^{*}} \mathbb{D}$, Collins Mitambo ${ }^{3}$, Dean Everett ${ }^{1,4}$, Anna Maria Geretti ${ }^{2}$ and Melita A Gordon ${ }^{1,2}$
}

\begin{abstract}
Background: Viral hepatitis is an important public health issue in sub-Saharan Africa. Due to rising mortality from cirrhosis and hepatocellular carcinoma and limited implementation of screening and treatment programmes, it has been characterised as a neglected tropical disease. Synthesis of the existing evidence on the epidemiology of viral hepatitis B, C and D in Malawi is required to inform policy and identify research gaps.

Methods: We searched Pubmed, EMBASE and Scopus for studies reporting the epidemiology of viral hepatitis B, C and D in Malawi from 1990 to 2018. Articles reporting prevalence estimates were included provided they described details of participant selection, inclusion criteria and laboratory methods (detection of HBsAg, anti-HCV or anti-HDV antibody, HCV antigen or HCV RNA or HDV RNA). We assessed study quality using a prevalence assessment tool. Where appropriate, a pooled prevalence was calculated using a DerSimonian Laird random effects model.
\end{abstract}

Results: Searches identified 199 studies, 95 full text articles were reviewed and 19 articles were included. Hepatitis B surface antigen ( $\mathrm{HBsAg}$ ) seroprevalence was assessed in 14 general population cohorts. The pooled prevalence among adults was $8.1 \%(95 \% \mathrm{Cl} 6.1,10.3)$. In 3 studies where HBsAg was stratified by HIV status, no effect of HIV on HBsAg prevalence was observed (OR $1.2(95 \% \mathrm{Cl}: 0.8,1.6, p=0.80)$ ). In a single study of HIV/HBV infected individuals, antihepatitis D antibody (anti-HDV) prevalence was low (1.5\%). HCV antibody prevalence (anti-HCV) ranged from 0.7 to 18.0\% among 12 cohorts in general populations. Among three studies which used PCR to confirm current infection, the pooled rate of HCV RNA confirmation among anti-HCV positive individuals was only $7.3 \%$ (95\% Cl: $0.0,24.3)$.

Conclusions: Hepatitis B is highly prevalent in Malawi. There is a paucity of epidemiological data from rural areas where $85 \%$ of the population reside, and the Northern region. Priority research needs include large-scale representative community studies of HBV, HDV and HCV seroprevalence, assessment of children following introduction of the HBV vaccine in 2002, prevalence estimates of viral hepatitis among individuals with cirrhosis and HCC and data on HCV prevalence using PCR confirmation, to support a viral hepatitis strategy for Malawi.

Keywords: Epidemiology, Viral hepatitis, Hepatitis B, Hepatitis C, Hepatitis D, Malawi, Sub-Saharan Africa

\section{Background}

Viral hepatitis is the principal cause of liver cirrhosis and hepatocellular carcinoma (HCC) in sub-Saharan Africa [1]. Due to limited availability of screening and treatment programmes, it has been characterised as a neglected tropical disease [2]. In contrast with HIV, malaria and tuberculosis, where public health interventions have resulted in substantial reductions in mortality, viral

\footnotetext{
* Correspondence: a.stockdale@liverpool.ac.uk

1 Malawi Liverpool Wellcome Trust Clinical Research Programme, Chichiri 3, PO Box 30096, Blantyre, Malawi

${ }^{2}$ Institute of Infection and Global Health, University of Liverpool, Ronald Ross Building, 8 West Derby Street, Liverpool L69 7BE, UK

Full list of author information is available at the end of the article
}

hepatitis-associated mortality is rising: cirrhosis and HCC were the cause of an estimated $3.2 \%$ of adult deaths in 2005, rising to $4 \%$ in 2016 [3, 4]. In Malawi, the cirrhosis-associated mortality rate has been ranked in the top global decile [5]. Across Southern Africa, an estimated $50-64 \%$ of cases of HCC are attributable to viral hepatitis, and with limited treatment options outcomes are poor with an estimated annual mortality to incidence ratio of $96 \%$ [6-8]. HCC has been shown to occur in a younger age group among individuals in sub-Saharan Africa and in HBV-associated cases (relative to $\mathrm{HCV}$-associated cases), contributing to increased disease impact $[9,10]$.

(c) The Author(s). 2018 Open Access This article is distributed under the terms of the Creative Commons Attribution 4.0 International License (http://creativecommons.org/licenses/by/4.0/), which permits unrestricted use, distribution, and 
Data on the epidemiology of viral hepatitis are required to inform an effective public health response. In the Global Health Sector Strategy on Viral Hepatitis 2016-2021, the World Health Organisation (WHO) has identified the need to define the national disease burden and strategically target limited resources to counter the local epidemic. There is a WHO call for data on transmission and risk factors, to identify specific populations at risk and to quantify the health burden in terms of cirrhosis and hepatocellular carcinoma [11].

The Malawi Ministry of Health $(\mathrm{MoH})$ has resolved to respond to viral hepatitis in a concerted and strategic manner. As part of the response, a National Viral Hepatitis Unit has been created in the $\mathrm{MoH}$ to guide the direction of policy and practice. In order to consolidate the current available evidence on epidemiology of viral hepatitis, identify the gaps in knowledge, practice and policy, we aimed to conduct a systematic review of all published epidemiological data on the prevalence of chronic hepatitis B, C and D in Malawi and identify further research needs.

\section{Methods}

Searches were performed in Pubmed, Scopus and EMBASE using the search terms Malawi AND (hepatitis or hepatitis $\mathrm{B}$ or $\mathrm{HBV}$ or $\mathrm{HBsAg}$ or hepatitis $\mathrm{C}$ or $\mathrm{HCV}$ or anti-HCV or HCV antibody or core HCV antigen or HCVcAg or HCV RNA or hepatitis D or HDV or anti-HD or anti-HDV or HDV IgG or HDV RNA or viral hepatitis). (Additional file 1: Table S1) Medical subject headings $[\mathrm{MeSH}]$ in Pubmed and EMBASE thesaurus tools were employed. Searches were restricted to publications between 1 Jan 1990 and 1 February 2018 with a search update on 22 June 18, to identify published data from the past 28 years (Fig. 1).

Data were grouped into two categories: "general populations" which provided data from potentially representative community samples, pregnant women, or blood donors; "HIV positive populations" adults or women, or children receiving routine HIV care, and "special groups", comprising populations likely to be unrepresentative of the general population such as medical inpatients, prisoners or medical students.

Studies reporting detection of hepatitis B surface antigen (HBsAg), or total or IgG anti-hepatitis delta antibody (anti-HDV) or HDV RNA among HBsAg positive people, or anti-hepatitis $\mathrm{C}$ antibody (anti-HCV), hepatitis $\mathrm{C}$ core antigen $(\mathrm{HCVCAg})$ or $\mathrm{HCV}$ RNA were included, provided they presented details of selection and inclusion criteria and described the laboratory methods used.

\section{Data extraction and quality assessment}

We conducted this review in accordance with PRISMA guidelines [12]. We extracted details of study design, participant characteristics (age and gender distribution, population group), sampling method, dates, study locations, laboratory test used and prevalence estimates. A quality assessment tool for prevalence estimates was used and study quality was independently evaluated by two authors (AS, CM) with discordance resolved by discussion [13].

\section{Statistical analysis}

Confidence intervals for prevalence were calculated using the Wilson method. Pooled seroprevalence for hepatitis B was calculated with the DerSimonian-Laird random-effects model with Freeman-Tukey double arcsine transformation [14, 15]. A random effects model was applied due to anticipated heterogeneity. Study heterogeneity was assessed using the $\mathrm{I}^{2}$ statistic. Analyses were performed in Stata release 14.2 (College Station, TX, USA) using the metaprop package [16].

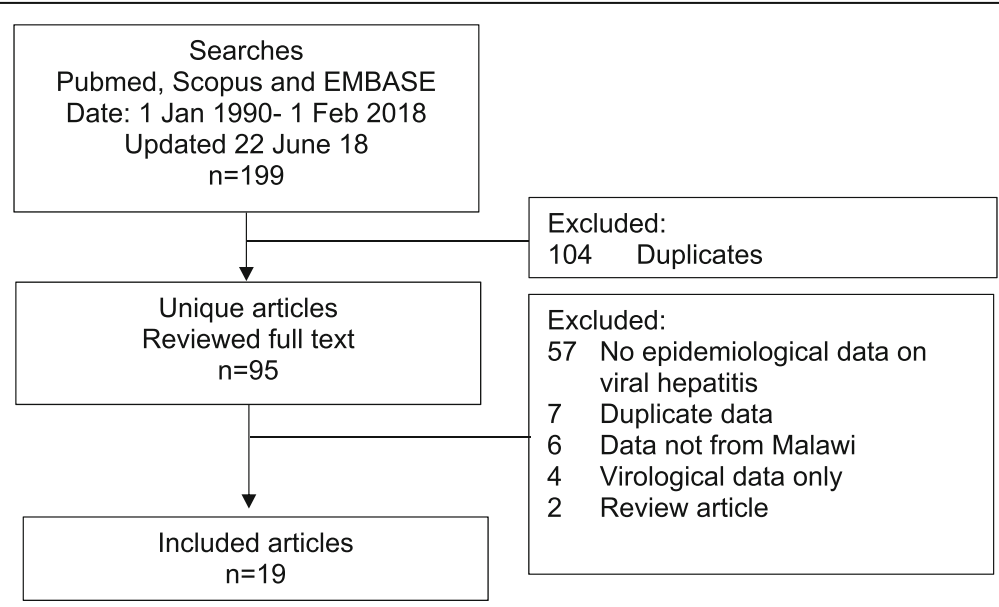

Fig. 1 Flowchart of literature searches 


\section{Results}

The literature search identified 199 studies. Following removal of duplicates, 95 full-text articles were reviewed and 19 studies that reported epidemiological data on hepatitis $\mathrm{B}, \mathrm{C}$ and $\mathrm{D}$ in diverse populations in Malawi were included (Fig. 1).

\section{Description of included studies}

The 19 included studies described a total of HBsAg seroprevalence data from 16 different cohorts that were general or HIV-positive populations (Table 1; Fig. 2) and three cohorts from specific unrepresentative subgroups (Table 2); hepatitis D antibody (anti-HDV) data was available from a single study (Table 3 ) and hepatitis $\mathrm{C}$ antibody (anti-HCV) data was available from 15 general or HIV-positive cohorts (Table 4; Fig. 4) and from four cohorts describing specific subgroups (Table 5). Fourteen of 18 studies were from urban centres.

\section{Hepatitis B prevalence}

HBsAg seroprevalence estimates ranged from 0.0 to $14.3 \%$ in general populations and 3.8 to $16.0 \%$ in

Table 1 Hepatitis B surface antigen (HBsAg) seroprevalence in Malawi: published data from 1990 to 2018

\begin{tabular}{|c|c|c|c|c|c|c|}
\hline Population & Ref & Year & Location & Laboratory method & $\begin{array}{l}\text { Prevalence } \\
\text { (n/total) }\end{array}$ & $\begin{array}{l}\text { Prevalence (\%), } \\
(95 \% \mathrm{Cl})\end{array}$ \\
\hline \multicolumn{7}{|l|}{ General Populations } \\
\hline Pregnant women & {$[20]$} & 1989-1994 & QECH, Blantyre & $\begin{array}{l}\text { MONOLISA HBSAg ULTRA } \\
\text { (Biorad) }\end{array}$ & $0 / 70$ & $0.0(0.0,5.2)$ \\
\hline $\begin{array}{l}\text { Pregnant women, at } \\
\text { delivery }\end{array}$ & {$[18]$} & 1993-1995 & Shire Valley & Bioelisa HBsAg (Biokit, S.A.) & $12 / 100$ & $12.0(7.0,19.8)$ \\
\hline Pregnant women & {$[20]$} & $2004-2008$ & $\begin{array}{l}\text { QECH, Health } \\
\text { Centres Blantyre }\end{array}$ & $\begin{array}{l}\text { MONOLISA HBsAg ULTRA } \\
\text { (Biorad) }\end{array}$ & $16 / 134$ & $11.9(7.5,18.5)$ \\
\hline $\begin{array}{l}\text { Male workers at } \\
\text { sugar estate }\end{array}$ & {$[17]$} & 1998 & Nchalo & $\begin{array}{l}\text { Auszyme monoclonal ElA } \\
\text { (Abbott) }\end{array}$ & $40 / 280$ & $14.3(10.7,18.9)$ \\
\hline $\begin{array}{l}\text { Community, rural } \\
\text { adults }\end{array}$ & {$[20]$} & 2001 & Mwanza District & $\begin{array}{l}\text { MONOLISA HBsAg ULTRA } \\
\text { (Biorad) }\end{array}$ & $7 / 98$ & $7.1(3.5,14.0)$ \\
\hline $\begin{array}{l}\text { Non-pregnant } \\
\text { women (intravaginal } \\
\text { MTZ gel RCT) }\end{array}$ & {$[20]$} & 2003-2005 & QECH, Blantyre & $\begin{array}{l}\text { MONOLISA HBSAg ULTRA } \\
\text { (Biorad) }\end{array}$ & $8 / 137$ & $5.8(3.0,11.1)$ \\
\hline $\begin{array}{l}\text { HIV-negative partners } \\
\text { in a serodiscordant } \\
\text { couple }\end{array}$ & {$[19]$} & $2007-2010$ & Blantyre Lilongwe & HBsAg ELISA NS & $26 / 433$ & $6.0(4.1,8.7)$ \\
\hline Blood donors & {$[21]$} & 2001 & Ntechu & HBsAg ELISA NS & $13 / 159$ & $8.2(4.8,13.5)$ \\
\hline \multicolumn{7}{|l|}{ HIV-positive populations } \\
\hline $\begin{array}{l}\text { HIV-positive pregnant } \\
\text { women, at delivery }\end{array}$ & {$[18]$} & 1993-1995 & Shire Valley & Bioelisa HBsAg (Biokit, S.A.) & $8 / 50$ & $16.0(8.3,28.5)$ \\
\hline $\begin{array}{l}\text { HIV-positive pregnant } \\
\text { women }\end{array}$ & {$[20]$} & $2000-2004$ & QECH, Blantyre & $\begin{array}{l}\text { MONOLISA HBSAg ULTRA } \\
\text { (Biorad) }\end{array}$ & $6 / 156$ & $3.8(1.8,8.1)$ \\
\hline $\begin{array}{l}\text { HIV-positive pregnant } \\
\text { women }\end{array}$ & {$[22]$} & 2004-2009 & Lilongwe & $\begin{array}{l}\text { Vitros Chemiluminescence } \\
\text { Immunoassay (Ortho Clinical } \\
\text { Diagnostics) }\end{array}$ & $103 / 2049$ & $5.0(4.2,6.1)$ \\
\hline $\begin{array}{l}\text { HIV-positive pregnant } \\
\text { women }\end{array}$ & {$[23]$} & 2008-2009 & Blantyre & $\begin{array}{l}\text { Murex HBsAg Version } 3 \\
\text { with Confirmatory Assay } \\
\text { (Murex Biotech) }\end{array}$ & $27 / 309$ & $8.7(6.1,12.4)$ \\
\hline $\begin{array}{l}\text { HIV positive: male } \\
\text { workers at sugar estate }\end{array}$ & {$[17]$} & 1998 & Nchalo & $\begin{array}{l}\text { Auszyme monoclonal ElA } \\
\text { (Abbott) }\end{array}$ & $32 / 189$ & $16.9(12.3,22.9)$ \\
\hline HIV-positive adults & {$[24]$} & 2005 & QECH, Blantyre & Bioelisa HBsAg (Biokit, S.A.) & $20 / 300$ & $6.7(4.4,10.1)$ \\
\hline $\begin{array}{l}\text { HIV positive adults, } \\
\text { ART starters }\end{array}$ & {$[25]$} & 2007-2009 & QECH, Blantyre & Bioelisa HBsAg (Biokit, S.A.) & $133 / 1117$ & $11.9(10.1,13.9)$ \\
\hline $\begin{array}{l}\text { HIV-positive adults in } \\
\text { sero-discordant couple }\end{array}$ & {$[19]$} & 2007-2010 & Blantyre Lilongwe & HBsAg ELISA NS & $26 / 432$ & $6.0(4.1,8.7)$ \\
\hline HIV-infected children & {$[26]$} & 2008-2010 & Lilongwe & $\begin{array}{l}\text { Genetic Systems HBsAg } 3.0 \\
\text { (Bio-Rad) }\end{array}$ & $2 / 91$ & $2.2(0.6,7.7)$ \\
\hline
\end{tabular}

Abbreviations: QECH Queen Elizabeth Central Hospital, Blantyre. This is a tertiary referral hospital, MTZ metronidazole, RCT randomised controlled trial. Biorad: HBsAg ELISA, Biorad, Hercules, CA, USA; Bioelisa: HBsAg 3.0 Biokit SA Barcelona, Spain; Ortho Clinical Diagnositics: Raritan, New Jersey, United States: Siemens: ADVIA Centaur, Siemens, Munich, Germany; Abbott: Murex HBsAg, Abbott, Illinois, USA; HBsAg ELISA NS- manufacturer not specified 


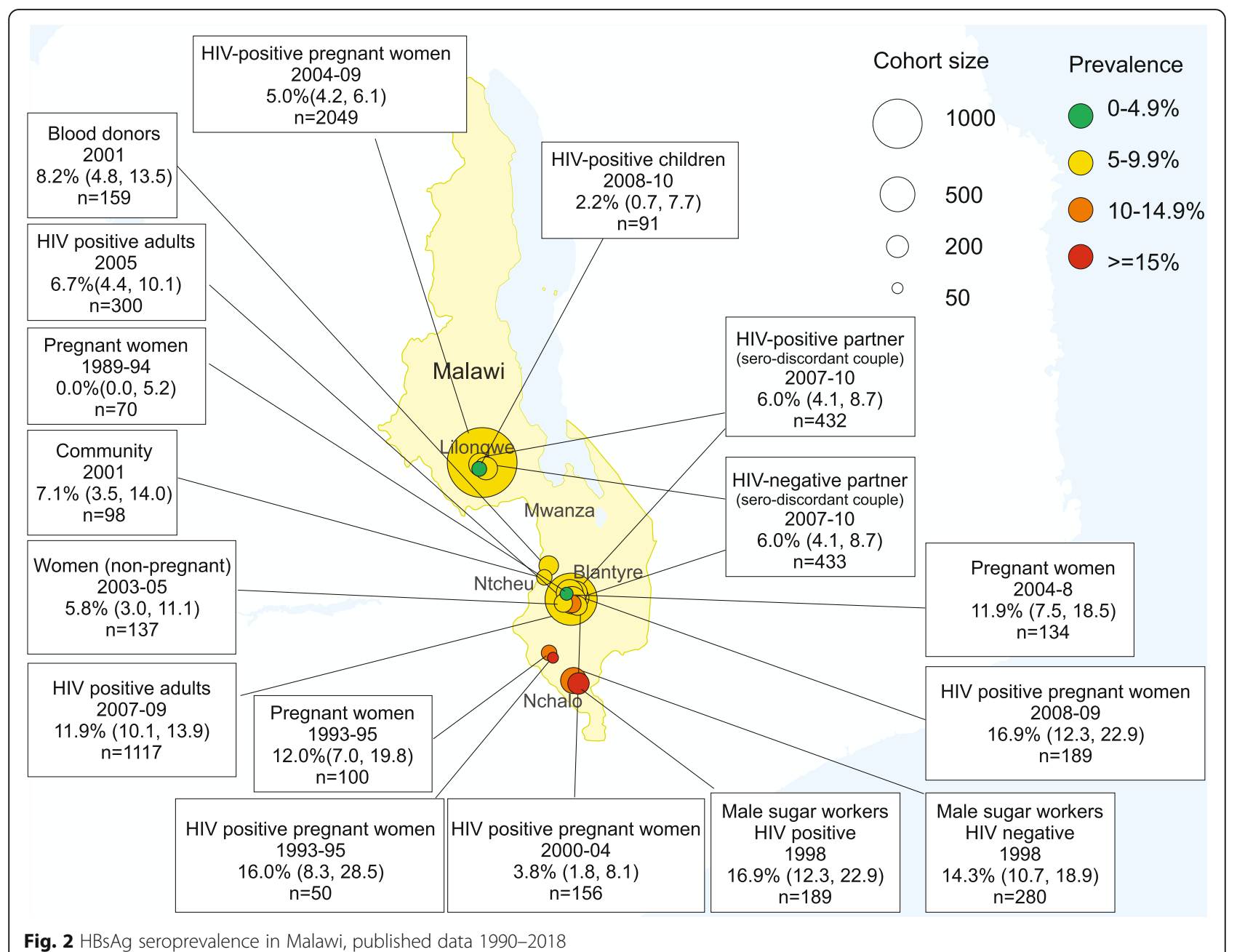

Fig. 2 HBsAg seroprevalence in Malawi, published data 1990-2018

HIV positive populations (Table 1). One small study reporting from HIV positive children aged 3 months - 15 years (median 36 months) reported seroprevalence of $2.2 \%$ [95\% confidence interval (CI) 0.6, 7.7]. This study did not estimate HBV vaccine efficacy as the vaccine was introduced in Malawi in 2002 and both vaccinated and non-vaccinated cohorts were combined. Pooled estimates of HBsAg seroprevalence among adult general populations was $7.6 \%$ (95\% CI 4.6, 11.2) and $8.5(95 \%$ CI 5.7, 11.7) in HIV positive populations (Fig. 3). The overall pooled estimate of HBsAg seroprevalence in adults was $8.1 \%$ (95\% CI $6.1,10.3)$.
No significant difference in HBsAg prevalence was noted between HIV-positive and -negative populations $(p=0.74)$. The effect of HIV status on HBV seroprevalence was assessed directly in three studies, with a total of 1484 participants, that tested HBsAg prevalence, stratified by HIV status within the same population. These populations comprised male workers at a sugar factory $(n=469)$ [17], pregnant women recruited at delivery $(n=150)[18]$ and HIV positive and negative serodiscordant couples recruited for a randomised control trial of antiretroviral therapy for prevention of transmission $(n=865)$ [19]. Among the three groups, the odds ratio of $\mathrm{HBsAg}$ positivity among HIV positive compared

Table 2 HBsAg seroprevalence among special unrepresentative populations in Malawi: Published data from 1990 to 2018

\begin{tabular}{lccllll}
\hline Population & Ref & Year & Location & Laboratory method & $\begin{array}{l}\text { Prevalence } \\
(\mathrm{n} / \text { total })\end{array}$ & $\begin{array}{l}\text { Prevalence } \\
(\%,(95 \% \text { CI) }\end{array}$ \\
\hline Adult medical inpatients & {$[27]$} & 2004 & Medical ward, QECH, Blantyre & Determine HBsAg Rapid Test (Alere) & $34 / 194$ & $17.5(12.8,23.5)$ \\
Prisoners & {$[28]$} & 2007 & Chichiri Prison, Blantyre & HBsAg kit (Abbott) & $5 / 164$ & $3.0(1.3,6.9)$ \\
Medical students & {$[29]$} & 2013 & College of Medicine, Blantyre & SD Bioline Rapid Test (Alere) & $0 / 89$ & $0.0(0.0,4.9)$ \\
\hline
\end{tabular}

Abbreviations: QECH Queen Elizabeth Central Hospital, $A R T$ antiretroviral therapy 
Table 3 Published data on hepatitis D seroprevalence in Malawi among HBsAg positive individuals

\begin{tabular}{lllllll}
\hline Population & Ref & Year & Location & Method & Prevalence $(\mathrm{n} /$ total) & Prevalence $(\%,(95 \%$ Cl)) \\
\hline HIV-HBV infected adults & {$[30]$} & $2007-2009$ & HIV clinic, QECH Blantyre & 1. ETI-AB-DELTAK (Diasorin) & $2 / 133$ & $1.5(0.4,5.3)$ \\
& & & & 2. HDV RNA PCR (in-house) & $0 / 133$ & $0.0(0.0,2.8)$ \\
\hline
\end{tabular}

Table 4 Published data on hepatitis C seroprevalence in Malawi

\begin{tabular}{|c|c|c|c|c|c|c|}
\hline Population & Ref & Year & Location & Method & $\begin{array}{l}\text { Prevalence } \\
\text { (n/total) }\end{array}$ & $\begin{array}{l}\text { Prevalence }(\%, \\
(95 \% \mathrm{Cl}))\end{array}$ \\
\hline \multicolumn{7}{|l|}{ General Populations } \\
\hline Pregnant women & {$[20]$} & 1989-1994 & QECH, Blantyre & Anti-HCV (Biorad) & $2 / 70$ & $2.9(0.8,9.8)$ \\
\hline $\begin{array}{l}\text { Pregnant women, } \\
\text { at delivery }\end{array}$ & [18] & 1993-1995 & Shire Valley & $\begin{array}{l}\text { Ortho anti-HCV (Ortho } \\
\text { Diagnostics) }\end{array}$ & $18 / 100$ & $18.0(11.7,26.7)$ \\
\hline Pregnant women & [20] & 2004-2008 & $\begin{array}{l}\text { QECH, Health } \\
\text { Centres Blantyre }\end{array}$ & Anti-HCV (Biorad) & $8 / 138$ & $5.8(3.0,11.0)$ \\
\hline $\begin{array}{l}\text { Community, rural } \\
\text { adults }\end{array}$ & {$[20]$} & 2001 & Mwanza District & Anti-HCV (Biorad) & 9/99 & $9.0(4.9,16.4)$ \\
\hline $\begin{array}{l}\text { Non-pregnant } \\
\text { women (intravaginal } \\
\text { MTZ gel RCT) }\end{array}$ & {$[20]$} & 2003-2005 & QECH, Blantyre & Anti-HCV (Biorad) & $9 / 146$ & $6.1(3.3,11.3)$ \\
\hline $\begin{array}{l}\text { Male workers at sugar } \\
\text { estate }\end{array}$ & [17] & 1998 & Nchalo & $\begin{array}{l}\text { Ortho anti-HCV (Ortho } \\
\text { Diagnostics) }\end{array}$ & $35 / 279$ & $10.0(7.0,14.1)$ \\
\hline Blood donors & {$[32]$} & 1996 & KCH, Lilongwe & $\begin{array}{l}\text { Anti-HCV EIA (Roche) } \\
\text { Confirmed with Anti-HCV } \\
\text { (Abbott) }\end{array}$ & $4 / 100$ & $4.0(1.6,9.8)$ \\
\hline \multirow[t]{2}{*}{ Blood donors } & {$[21]$} & 2001 & Ntechu & 1. Murex anti-HCV & $10 / 148$ & $6.8(3.7,12.0)$ \\
\hline & & & & $\begin{array}{l}\text { 2. HCV RNA by in-house } \\
P C R\end{array}$ & $1 / 140$ & $0.7(0.1,3.9)$ \\
\hline \multicolumn{7}{|l|}{ HIV positive populations } \\
\hline $\begin{array}{l}\text { HIV-positive pregnant } \\
\text { women, at delivery }\end{array}$ & [18] & 1993-1995 & Shire Valley & $\begin{array}{l}\text { Ortho anti-HCV (Ortho } \\
\text { Diagnostics) }\end{array}$ & $6 / 50$ & $12.0(5.6,23.8)$ \\
\hline \multirow[t]{2}{*}{$\begin{array}{l}\text { HIV-positive pregnant } \\
\text { women }\end{array}$} & {$[23]$} & 2008-2009 & Blantyre & $\begin{array}{l}\text { 1. Innotest HCV Ab IV } \\
\text { (Innogenetics), }\end{array}$ & $8 / 309$ & $2.6(1.3,5.0)$ \\
\hline & & & & $\begin{array}{l}\text { 2. Versant HCV RNA } 1.0 \\
\text { assay (Siemens) }\end{array}$ & $1 / 309$ & $0.3(0.1,1.8)$ \\
\hline HIV positive patients & {$[24]$} & 2005 & QECH, Blantyre & $\begin{array}{l}\text { Monolisa HCV Ag-Ab } \\
\text { (Biorad) confirmed with } \\
\text { ADVIA Centaur anti-HCV) } \\
\text { and InnoLIA HCV } \\
\text { immunoassay } \\
\text { (Innogenetics) }\end{array}$ & $17 / 300$ & $5.7(3.6,8.9)$ \\
\hline $\begin{array}{l}\text { HIV-positive male } \\
\text { workers at sugar estate }\end{array}$ & {$[17]$} & 1998 & Nchalo & $\begin{array}{l}\text { Ortho anti-HCV Ab (Ortho } \\
\text { Clinical Diagnostics) }\end{array}$ & $28 / 280$ & $10.0(7.0,14.1)$ \\
\hline $\begin{array}{l}\text { HIV-positive pregnant } \\
\text { women }\end{array}$ & {$[20]$} & 2000-2004 & QECH, Blantyre & Anti-HCV (Biorad) & $8 / 148$ & $5.4(2.8,10.3)$ \\
\hline \multirow[t]{2}{*}{$\begin{array}{l}\text { HIV positive adults } \\
\text { starting ART }\end{array}$} & [31] & 2014-15 & Lilongwe & $\begin{array}{l}\text { 1. HCV IgG Architect } \\
\text { (Abbott) }\end{array}$ & $5 / 227$ & $2.2(0.9,5.1)$ \\
\hline & & & & $\begin{array}{l}\text { 2. RealTime HCV RNA } \\
\text { (Abbott) }\end{array}$ & $0 / 227$ & $0.0(0.0,1.7)$ \\
\hline $\begin{array}{l}\text { HIV positive patients } \\
\text { on ART for }>10 \text { years }\end{array}$ & [33] & 2014-16 & Chiradzulu & $\begin{array}{l}\text { OraQuick HCV Rapid } \\
\text { antibody test (Orasure) }\end{array}$ & $2 / 385$ & $0.5(0.1,1.9)$ \\
\hline
\end{tabular}


Table 5 Published data on hepatitis C seroprevalence among special unrepresentative populations in Malawi: Published data from 1990 to 2018

\begin{tabular}{|c|c|c|c|c|c|c|}
\hline Population & Ref & Year & Location & Method & $\begin{array}{l}\text { Prevalence } \\
\text { (n/total) }\end{array}$ & $\begin{array}{l}\text { Prevalence } \\
(\%,(95 \% \text { CI)) }\end{array}$ \\
\hline Prisoners & {$[28]$} & 2007 & Chichiri Prison, Blantyre & Anti-HCV (Biotec) & $0 / 164$ & $0.0(0.0,2.3)$ \\
\hline $\begin{array}{l}\text { Adult inpatients (Dermatology, } \\
\text { Urology) }\end{array}$ & {$[32]$} & 1996 & $\mathrm{KCH}$, Lilongwe & $\begin{array}{l}\text { Anti-HCV EIA (Roche) Confirmed } \\
\text { with Anti-HCV (Abbott) }\end{array}$ & $13 / 333$ & $3.9(2.3,6.6)$ \\
\hline Adult medical inpatients & {$[27]$} & 2004 & $\begin{array}{l}\text { Medical ward, QECH, } \\
\text { Blantyre }\end{array}$ & $\begin{array}{l}\text { HCV Ag/Ab (Monolisa, Biorad) } \\
\text { confirmed with Immunoassay } \\
\text { (Innogenetics) }\end{array}$ & $9 / 202$ & $4.5(2.4,8.2)$ \\
\hline \multirow{2}{*}{$\begin{array}{l}\text { Malawian women and children } \\
\text { with childhood malignancies }\end{array}$} & \multirow[t]{2}{*}[34]{} & \multirow[t]{2}{*}{$2006-10$} & \multirow[t]{2}{*}{ QECH, Blantyre } & HBV ELISA (MP Biomedicals) & Mothers: 2/418 & $0.5(0.1,1.7)$ \\
\hline & & & & $\begin{array}{l}\text { Confirmed by HCV BLOT (MP } \\
\text { Biomedicals) }\end{array}$ & Children: 1/418 & $0.2(0.0,1.3)$ \\
\hline
\end{tabular}

Abbreviations: Biotec: Dorset, United Kingdom; Roche: Basel, Switzerland; Abbott: Illinois, USA; Innogenetics: Ghent, Belgium; MP Biomedicals: California, USAKCH Kamuzu Central Hospital, QECH Queen Elizabeth Central Hospital, HCV hepatitis C virus

to HIV negative individuals from within the same population was $1.2(95 \% \mathrm{CI} 0.8,1.6, p=0.80)$, indicating no evidence of association between HBV infection and HIV infection status. (Fig. 4).

Studies among three unrepresentative groups deemed at altered risk of $\mathrm{HBV}$ infection: (adult medical inpatients, prisoners and medical students) found $\mathrm{HBsAg}$ prevalence rates of $17.5 \%, 3.0 \%$ and $0 \%$ respectively (Table 2).

\section{Hepatitis D prevalence}

A single study was available reporting HDV prevalence among $\mathrm{HIV} / \mathrm{HBV}$ co-infected individuals commencing ART in Blantyre [30] (Table 3). This demonstrated

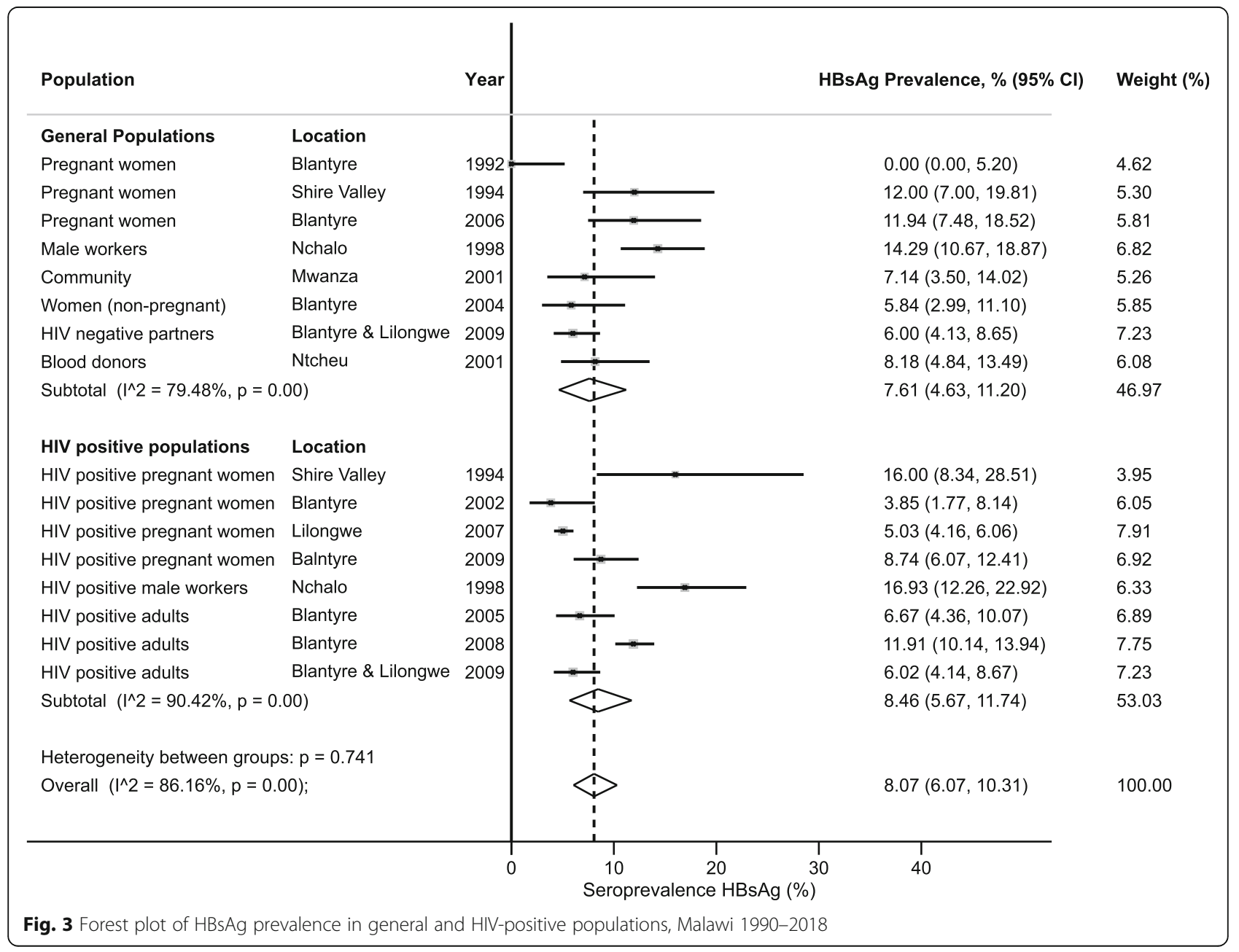




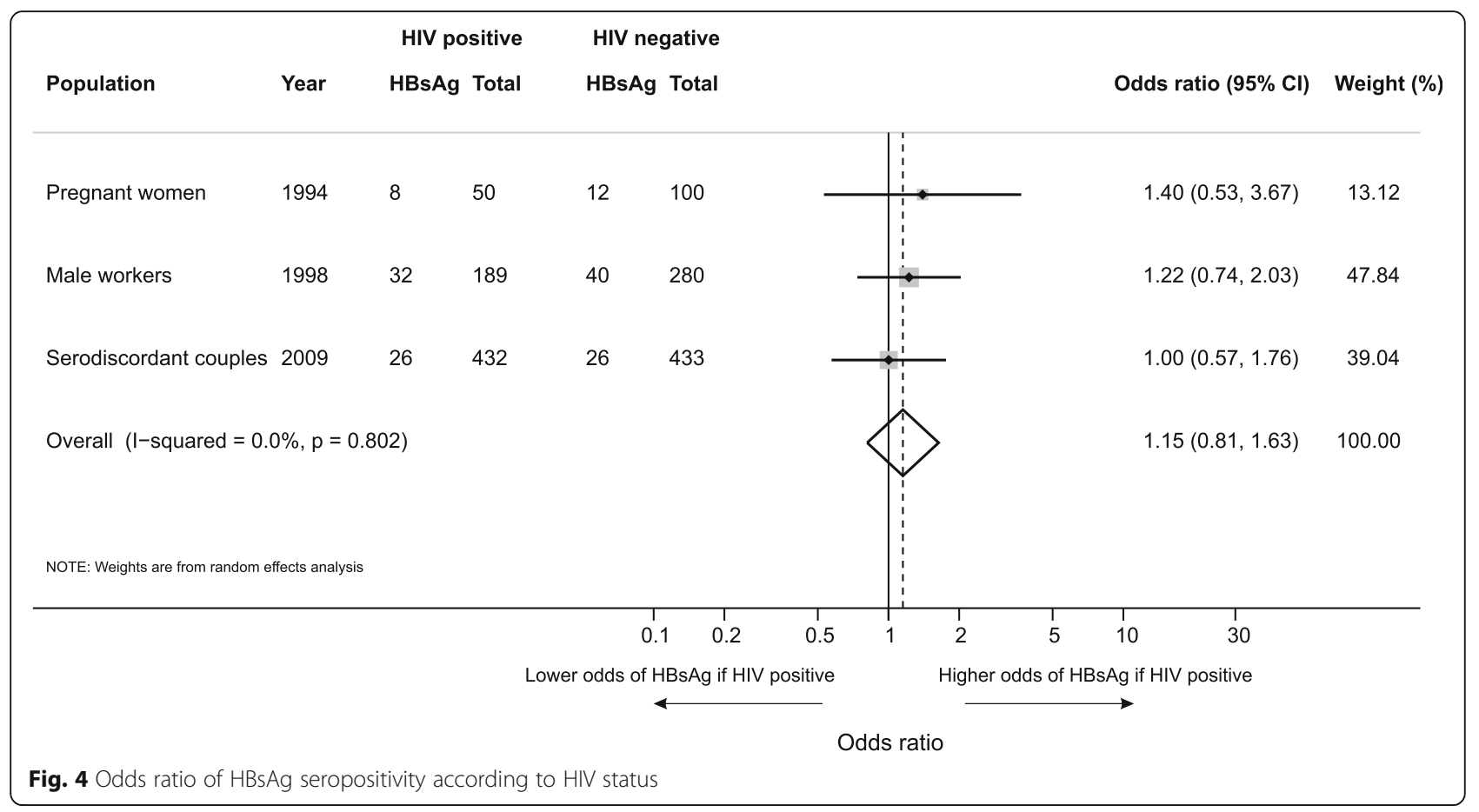

anti-HDV prevalence of $2 / 133(1.5 \%)$ but none of the participants were HDV RNA PCR positive.

\section{Hepatitis C prevalence}

Among general populations, anti-HCV prevalence ranged from 0.7 to $18.0 \%$ and among HIV-positive populations from 0.0 to $12.0 \%$. (Table 4, Fig. 5) Three studies confirmed active HCV infection using RNA PCR. These comprised a study of HIV-positive adults commencing ART in Lilongwe [31], a study of blood donors in Ntcheu [21] and a study of HIV-positive pregnant women in Blantyre [23]. In these studies, anti-HCV prevalence was $2.2,6.8$ and $2.6 \%$ respectively but $\mathrm{HCV}$ RNA PCR demonstrated active HCV prevalence of $0,0.7$ and $0.3 \%$ respectively, with a pooled rate of HCV RNA confirmation among anti-HCV positive participants of 7.3\% (95\% CI 0.0-24.3).

Among four studies assessing $\mathrm{HCV}$ prevalence in unrepresentative special subgroups comprising: prisoners; medical inpatients in Blantyre and Lilongwe; and children with malignancies and their mothers, the prevalence of anti-HCV was $0 ; 3.9$ and $4.5 ; 0.2$ and $0.5 \%$ respectively (Table 5 ).

\section{Discussion}

In this systematic review, we have compiled the existing epidemiological evidence on HBV, HCV and HDV prevalence in Malawi and have highlighted a number of key findings and important knowledge gaps. Data from studies reporting from general and HIV-infected populations showed a pooled $\mathrm{HBsAg}$ seroprevalence estimate of $8.1 \%$ (95\% CI 6.1, 10.3). This finding is in keeping with regional estimates from Mozambique (8.3\%), Tanzania (7.2\%) and Zambia (6.1\%) [35]. Our study has benefitted from the inclusion of significantly more data than previous estimates for Malawi [35, 36]. We noted that available data were biased toward the two main urban centres of Lilongwe and Blantyre, that the Northern region was under-represented and that there were no nationally representative community survey data.

Hepatitis $\mathrm{C}$ antibody seroprevalence estimates ranged from 2.9 to $18 \%$ from general or HIV-infected populations. Among the three available studies that reported HCV RNA confirmation, only $7.3 \%$ of 676 participants with anti-HCV antibody were confirmed to have $\mathrm{HCV}$ RNA replication. This finding has been consistent with other cohorts across the region and highlights issues with using anti-HCV as the basis for obtaining epidemiological estimates in the absence of confirmatory testing [37]. Confirmation of anti-HCV results with PCR or core $\mathrm{HCV}$ antigen testing are required to obtain reliable prevalence estimates [38]. Accordingly, due to the paucity of studies reporting PCR data, a pooled HCV prevalence estimate was not provided in this review. Furthermore, an assessment of possible association between HCV, HBV and HIV infection was not possible based on the limited data. Based on the available evidence, it is likely that HCV prevalence is low in Malawi, and was below 1\% in all studies using RNA confirmation $[21,23,31]$, but larger representative samples employing confirmatory PCR testing are required to confirm these findings. Further work to establish whether false positive 


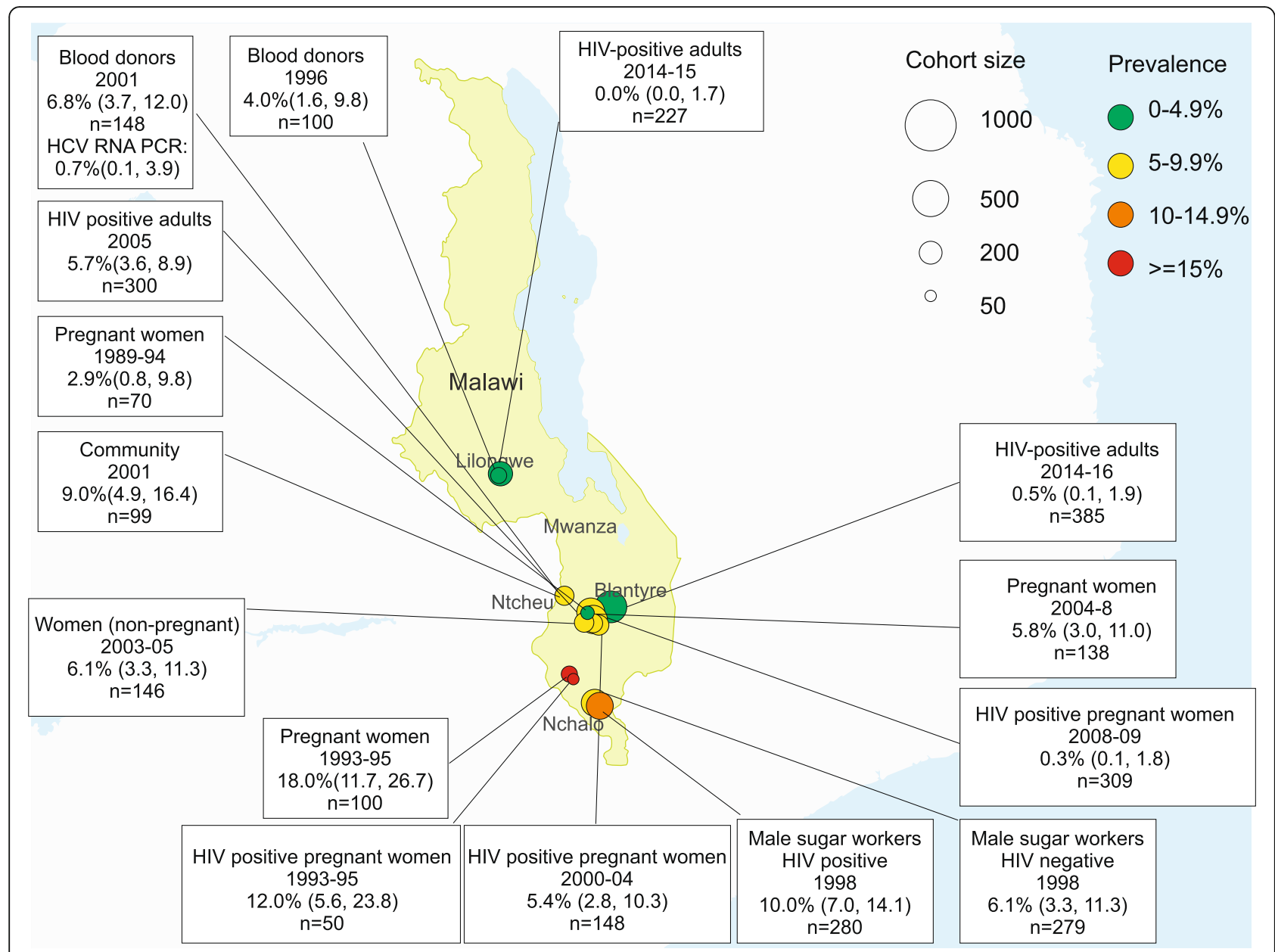

Fig. 5 Prevalence of hepatitis C antibody: published data 1990-2018

anti-HCV antibody tests or failure of HCV RNA assays to detect local HCV strains is required, particularly in view of the paucity of available genotypic $\mathrm{HCV}$ data from sub-Saharan Africa [39].

Only a single study reporting HDV prevalence was available, demonstrating a low rate of anti-HDV among HIV/HBV co-infected patients in Blantyre (1.5\%), with none of the participants showing replication of HDV RNA by PCR. This finding is in keeping with available limited data demonstrating a low rate of HDV seroprevalence from Southern Africa relative to Central or West Africa, though the paucity of available data from the Southern Africa region should be noted [30]. Due to the rapid progression to fatal liver disease associated with $\mathrm{HBV} / \mathrm{HDV}$ superinfection or co-infection, cross-sectional community estimates of HDV seroprevalence are unlikely to reliably estimate the true burden of disease caused by HDV. Studies of hospitalised patients with well-characterised liver disease are required and will facilitate the ascertainment of the attributable fraction of viral hepatitis to liver disease [40].
There are several limitations in this analysis, highlighted by our assessment of study quality (Additional file 2: Table S2). The epidemiological evidence presented in this study is drawn from predominantly small cohorts studies in diverse populations employing convenience sampling. A striking bias toward urban centres was observed with only four of 18 included studies drawn from rural areas, despite an estimated $85 \%$ of the Malawian population residing in rural areas [41]. There were no available data from the Northern region of Malawi, where $13 \%$ of the population live [41]. To overcome these issues of lack of nationally representative unbiased community data, the use of the demographic health survey using dried blood spot sampling represents a promising solution. Dried blood spots have excellent diagnostic performance relative to venous blood sampling for $\mathrm{HBsAg}$ and anti-HCV screening and this method has been recently recommended for large surveys by the WHO [38]. Use of dried blood spots for hepatitis D screening of the demographic health survey has recently been used in Burkina Faso [42], and represent an efficient method 
to obtain samples without requiring a cold chain or venepuncture.

The finding of lack of an association between hepatitis B seroprevalence and HIV status is in keeping with previous studies from sub-Saharan Africa [43]. This is likely due to distinct transmission epidemiology, with hepatitis B predominantly acquired perinatally or horizontally in early childhood, and HIV acquired predominantly during adolescence or adulthood by sexual transmission in sub-Saharan Africa. By contrast, recent evidence of incident transmission of HBV in HIV-infected adults has highlighted the risk of HBV acquisition in adulthood [44]. Hepatitis B vaccination is provided as a component of the pentavalent vaccine (also containing, diphtheria, tetanus, pertussis and Haemophilis influenzae type B) in the expanded programme of immunisation schedule for Malawian infants, provided at 6,10 and 14 weeks since 2002. The Demographic Health Survey 2015-16 estimated 3-dose coverage of the vaccine of $93.0 \%$, with consistently high coverage exceeding $90 \%$, regardless of socioeconomic status or geographic location [45]. The WHO has recently proposed that gathering data on hepatitis B seroprevalence among a vaccinated cohort at 5 years of age is a priority in order to generate evidence on the efficacy of HBV vaccination programmes and this is a priority area for research highlighted by this review [46].

\section{Conclusions}

Hepatitis B is highly prevalent in Malawi with an estimated seroprevalence among the general population of $8.1 \%$. HCV prevalence was below $1 \%$ in three general population cohorts that used nucleic amplification confirmatory testing. There is a need for representative unbiased community seroprevalence estimates of HBV, HDV and HCV prevalence. These should include confirmatory PCR testing to establish reliable $\mathrm{HCV}$ prevalence estimates. Future studies examining seroprevalence among community samples, with a particular focus on rural areas and the Northern region, are required. Assessment of the effectiveness of the hepatitis $B$ vaccination programme introduced in 2002 and data on HDV prevalence among HBsAg positive individuals represent further research priorities. Prevalence estimates of viral hepatitis among people with well-characterised liver disease with cirrhosis and HCC are required to ascertain the attributable fraction and burden of disease. These data will help to support a viral hepatitis strategy for Malawi, facilitate the introduction of screening and treatment programmes for $\mathrm{HBV}$ and $\mathrm{HCV}$ and begin to reverse the current trend of increasing viral hepatitis-associated mortality.

\section{Additional files}

Additional file 1: Table S1. Assessment of quality of included studies, Assessment of study quality using a prevalence quality assessment tool (PDF $52 \mathrm{~kb}$ )

Additional file 2: Table S2. Search Strategies. Search terms used for electronic databases Pubmed and Scopus (PDF 73 kb)

\section{Abbreviations}

Anti-HCV: hepatitis C virus antibody; Anti-HDV: anti-hepatitis C virus antibody: ART: antiretroviral therapy; DNA: deoxyribonucleic acid; EIA: Enzyme immunoassay; HBsAg: hepatitis B surface antigen; HBV: hepatitis B virus; HCC: hepatocellular carcinoma; HCV: hepatitis C virus; HDV: hepatitis D virus; KCH: Kamuzu Central Hospital, Lilongwe, Malawi (National tertiary referral hospital); MoH: Ministry of Health; PCR: polymerase chain reaction;

QECH: Queen Elizabeth Central Hospital, Blantyre, Malawi (National tertiary referral hospital); RNA: ribonucleic acid; WHO: World Health Organisation

\section{Funding}

AS is supported by a Wellcome Trust Clinical PhD Fellowship, grant 109130/ $Z / 15 / Z$. The funder had no role in the design of the study and collection, analysis, and interpretation of data nor in writing the manuscript.

\section{Availability of data and materials}

All data generated or analysed during this study are included in this published article.

\section{Authors' contributions}

AS performed the literature searches, extracted the data, performed statistical analyses, wrote the manuscript, CM performed quality assessment of included articles, reviewed and revised the manuscript, DE, AMG and MG developed the concept and study design, reviewed and revised the manuscript and assisted in data analysis and interpretation. All authors read and approved the final manuscript.

Ethics approval and consent to participate

Ethical approval was not required for this study as it is a systematic review of aggregate data from previously published studies.

Consent for publication

Not applicable.

\section{Competing interests}

The authors declare they have no competing interests.

\section{Publisher's Note}

Springer Nature remains neutral with regard to jurisdictional claims in published maps and institutional affiliations.

\section{Author details}

Malawi Liverpool Wellcome Trust Clinical Research Programme, Chichiri 3, PO Box 30096, Blantyre, Malawi. ${ }^{2}$ Institute of Infection and Global Health, University of Liverpool, Ronald Ross Building, 8 West Derby Street, Liverpool L69 7BE, UK. ${ }^{3} \mathrm{HIV}$ and AIDS Department, Malawi Ministry of Health, PO Box 30377, Lilongwe, Malawi. ${ }^{4}$ MRC Centre for Inflammation Research, The Queen's Medical Research Institute, University of Edinburgh, 47 Little France Crescent, Edinburgh EH16 4TJ, UK.

Received: 27 June 2018 Accepted: 1 October 2018

Published online: 12 October 2018

\section{References}

1. Lemoine M, Thursz MR. Battlefield against hepatitis B infection and HCC in Africa. J Hepatol. 2017;66(3):645-54

2. O'Hara GA, McNaughton AL, Maponga T, Jooste $P$, Ocama $P$, Chilengi $R$, Mokaya J, Liyayi Ml, Wachira T, Gikungi DM, et al. Hepatitis B virus infection as a neglected tropical disease. PLoS Negl Trop Dis. 2017;11(10):e0005842.

3. Global Burden of Disease Causes of Death Collaborators. Global, regional, and national age-sex specific mortality for 264 causes of death, 1980-2016: a 
systematic analysis for the global burden of disease study 2016. Lancet. 2017;390(10100):1151-210.

4. Global Burden of Disease Collaboratorative Network. Global Burden of Disease Study 2016 (GBD 2016) Results. Seattle: Institute for Health Metrics and Evaluation; 2017. http://ghdx.healthdata.org/gbd-results-tool Accessed 24 June 2018

5. Mokdad AA, Lopez AD, Shahraz S, Lozano R, Mokdad AH, Stanaway J, Murray CIL, Naghavi M. Liver cirrhosis mortality in 187 countries between 1980 and 2010: a systematic analysis. BMC Med. 2014;12:145.

6. Akinyemiju T, Abera S, Ahmed M, Alam N, Alemayohu MA, Allen C, AlRaddadi R, Alvis-Guzman N, Amoako Y, Artaman A, et al. The burden of primary liver Cancer and underlying etiologies from 1990 to 2015 at the global, regional, and National Level: results from the global burden of disease study 2015. JAMA Oncol. 2017;3(12):1683-91.

7. Parkin DM, Bray F, Ferlay J, Jemal A. Cancer in Africa 2012. Cancer Epidemiol Biomark Prev. 2014;23(6):953-66.

8. Yang JD, Mohamed EA, Aziz AO, Shousha HI, Hashem MB, Nabeel MM, Abdelmaksoud AH, Elbaz TM, Afihene MY, Duduyemi BM, et al. Characteristics, management, and outcomes of patients with hepatocellular carcinoma in Africa: a multicountry observational study from the Africa liver Cancer consortium. Lancet Gastroenterol Hepatol. 2017;2(2):103-11.

9. de Martel C, Maucort-Boulch D, Plummer M, Franceschi S. World-wide relative contribution of hepatitis $B$ and $C$ viruses in hepatocellular carcinoma. Hepatology. 2015;62(4):1190-200.

10. Yang JD, Gyedu A, Afihene MY, Duduyemi BM, Micah E, Kingham TP, Nyirenda M, Nkansah AA, Bandoh S, Duguru MJ, et al. Hepatocellular carcinoma occurs at an earlier age in Africans, particularly in association with chronic hepatitis B. Am J Gastroenterol. 2015;110(11):1629-31.

11. World Health Organisation. Global health sector strategy on viral hepatitis 2016-2021. Geneva: WHO; 2016.

12. Moher D, Liberati A, Tetzlaff J, Altman DG. Preferred reporting items for systematic reviews and meta-analyses: the PRISMA statement. BMJ. 2009; 339:b2535.

13. Munn Z, Moola S, Lisy K, Riitano D, Tufanaru C. Methodological guidance for systematic reviews of observational epidemiological studies reporting prevalence and cumulative incidence data. Int J Evid Based Healthc. 2015; 13(3):147-53.

14. Freeman MF, Tukey JW. Transformations related to the angular and the square root. Ann Math Stat. 1950;21(4):607-11.

15. Barendregt JJ, Doi SA, Lee YY, Norman RE, Vos T. Meta-analysis of prevalence. J Epidemiol Community Health. 2013;67(11):974-8.

16. Nyaga VN, Arbyn M, Aerts M. Metaprop: a Stata command to perform metaanalysis of binomial data. Archives Public Health. 2014;72(1):39.

17. Sutcliffe S, Taha TE, Kumwenda NI, Taylor E, Liomba GN. HIV-1 prevalence and herpes simplex virus 2, hepatitis C virus, and hepatitis B virus infections among male workers at a sugar estate in Malawi. J Acquir Immune Defic Syndr. 2002;31(1):90-7.

18. Ahmed SD, Cuevas LE, Brabin BJ, Kazembe P, Broadhead R, Verhoeff FH, Hart CA. Seroprevalence of hepatitis B and C and HIV in Malawian pregnant women. J Inf Secur. 1998;37(3):248-51.

19. Greer AE, Ou SS, Wilson E, Piwowar-Manning E, Forman MS, McCauley M, Gamble T, Ruangyuttikarn C, Hosseinipour MC, Kumarasamy N, et al. Comparison of hepatitis B virus infection in HIV-infected and HIV-uninfected participants enrolled in a multinational clinical trial: HPTN 052. J Acquir Immune Defic Syndr. 2017;76(4):388-93.

20. Taha TE, Rusie LK, Labrique A, Nyirenda M, Soko D, Kamanga M, Kumwenda J, Farazadegan H, Nelson K, Kumwenda N. Seroprevalence for hepatitis E and other viral Hepatitides among diverse populations. Malawi Emerg Infect Dis. 2015;21(7):1174-82.

21. Candotti D, Mundy C, Kadewele G, Nkhoma W, Bates I, Allain JP. Serological and molecular screening for viruses in blood donors from Ntcheu, Malawi: high prevalence of HIV-1 subtype $C$ and of markers of hepatitis $B$ and $C$ viruses. J Med Virol. 2001;65(1):1-5.

22. Chasela CS, Kourtis AP, Wall P, Drobeniuc J, King CC, Thai H, Teshale EH, Hosseinipour M, Ellington S, Codd MB, et al. Hepatitis B virus infection among HIV-infected pregnant women in Malawi and transmission to infants. J Hepatol. 2014;60(3):508-14.

23. Andreotti M, Pirillo MF, Liotta G, Jere H, Maulidi M, Sagno JB, Luhanga R, Amici R, Mancini MG, Gennaro E, et al. The impact of HBV or HCV infection in a cohort of HIV-infected pregnant women receiving a nevirapine-based antiretroviral regimen in Malawi. BMC Infect Dis. 2014;14:180.
24. Moore E, Beadsworth MB, Chaponda M, Mhango B, Faragher B, Njala J, Hofland HW, Davies J, Hart IJ, Beeching NJ, et al. Favourable one-year ART outcomes in adult Malawians with hepatitis B and C co-infection. J Inf Secur. 2010;61 (2):155-63.

25. Aoudjane S, Chaponda M, Gonzalez Del Castillo AA, O'Connor J, Noguera M, Beloukas A, Hopkins M, Khoo S, van Oosterhout JJ, Geretti AM. Hepatitis B virus sub-genotype $A 1$ infection is characterized by high replication levels and rapid emergence of drug resistance in HIV-positive adults receiving first-line antiretroviral therapy in Malawi. Clin Infect Dis. 2014;59(11):1618-26.

26. Varo R, Chris Buck W, Kazembe PN, Phiri S, Andrianarimanana D, Weigel R. Seroprevalence of CMV, HSV-2 and HBV among HIV-infected Malawian children: a cross-sectional survey. J Trop Pediatr. 2016;62(3):220-6.

27. Nyirenda M, Beadsworth MB, Stephany P, Hart CA, Hart IJ, Munthali C, Beeching $\mathrm{NJ}$, Zijlstra EE. Prevalence of infection with hepatitis $B$ and $C$ virus and coinfection with HIV in medical inpatients in Malawi. J Inf Secur. 2008;57(1):72-7.

28. Chimphambano C, Komolafe I, Muula A. Prevalence of HIV, HepBsAg and Hep C antibodies among inmates in Chichiri prison, Blantyre. Malawi Malawi Med J. 2007;19(3):107-10.

29. Chipetah F, Chirambo A, Billiat E, Shawa IT. Hepatitis B virus seroprevalence among Malawian medical students: a cross-sectional study. Malawi Med J. 2017;29(1):29-31.

30. Stockdale AJ, Chaponda M, Beloukas A, Phillips RO, Matthews PC, Papadimitropoulos A, King S, Bonnett L, Geretti AM. Prevalence of hepatitis $D$ virus infection in sub-Saharan Africa: a systematic review and metaanalysis. Lancet Glob Health. 2017;5(10):e992-e1003.

31. Demir M, Phiri S, Kaiser R, Chaweza T, Neuhann F, Tweya H, Fatkenheuer G, Steffen HM. HIV/hepatitis C virus co-infection among adults beginning antiretroviral therapy, Malawi. Emerg Infect Dis. 2016;22(11):2018-20.

32. Maida MJ, Daly CC, Hoffman I, Cohen MS, Kumwenda M, Vernazza PL. Prevalence of hepatitis $C$ infection in Malawi and lack of association with sexually transmitted diseases. Eur J Epidemiol. 2000;16(12):1183-4.

33. Loarec A, Carnimeo V, Maman D, Molfino L, Walter K, Nzomukunda Y, Muyindike W, Andrieux-Meyer I, Balkan S, Mwanga-Amumpaire J, et al. Low hepatitis $C$ virus prevalence among human immunodeficiency virus+ individuals in Sub-Saharan Africa. J Hepatol. 2017;66(1):S270-S271.

34. Fox JM, Newton R, Bedaj M, Keding A, Molyneux E, Carpenter LM, Martin F, Mutalima N. Prevalence of hepatitis $C$ virus in mothers and their children in Malawi. Tropical Med Int Health. 2015;20(5):638-42.

35. Schweitzer A, Horn J, Mikolajczyk RT, Krause G, Ott JJ. Estimations of worldwide prevalence of chronic hepatitis B virus infection: a systematic review of data published between 1965 and 2013. Lancet. 2015;386(10003):1546-55.

36. Rao VB, Johari N, du Cros P, Messina J, Ford N, Cooke GS. Hepatitis C seroprevalence and HIV co-infection in sub-Saharan Africa: a systematic review and meta-analysis. Lancet Infect Dis. 2015;15(7):819-24.

37. Sonderup MW, Afihene M, Ally R, Apica B, Awuku Y, Cunha L, Dusheiko G, Gogela N, Lohouès-Kouacou M-J, Lam P, et al. Hepatitis C in sub-Saharan Africa: the current status and recommendations for achieving elimination by 2030. Lancet Gastroenterol Hepatol. 2017;2(12):910-9.

38. World Health Organisation. Guidelines of hepatitis B and C testing. Geneva: WHO; 2017. http://www.who.int/hepatitis/publications/guidelines-hepatitisc-b-testing/en/ Accessed 26 June 18

39. Niebel M, Singer JB, Nickbakhsh S, Gifford RJ, Thomson EC. Hepatitis C and the absence of genomic data in low-income countries: a barrier on the road to elimination? Lancet Gastroenterol Hepatol. 2017;2(10):700-1.

40. Lempp FA, Ni Y, Urban S. Hepatitis delta virus: insights into a peculiar pathogen and novel treatment options. Nat Rev Gastroenterol Hepatol. 2016;13(10):580-9.

41. Government of Malawi. Population and housing census. Zomba: National Statistical Office; 2008.

42. Tuaillon E, Kania D, Gordien E, Van de Perre P, Dujols P. Epidemiological data for hepatitis D in Africa. Lancet Glob Health. 2018;6(1):e33.

43. Matthews PC, Geretti AM, Goulder PJ, Klenerman P. Epidemiology and impact of HIV coinfection with hepatitis B and hepatitis C viruses in subSaharan Africa. J Clin Virol. 2014;61(1):20-33.

44. Seremba E, Ssempijja V, Kalibbala S, Gray RH, Wawer MJ, Nalugoda F, Casper C, Phipps W, Ocama P, Serwadda D, et al. Hepatitis B incidence and prevention with antiretroviral therapy among HIV-positive individuals in Uganda. AIDS. 2017;31(6):781-6.

45. Government of Malawi. Malawi demographic and health survey 2015-16. Zomba: National Statistical Office; 2017.

46. World Health Organisation. World health statistics 2017: monitoring health for the sustainable development goals. Geneva: WHO; 2017. 